the Pilgrim Trust, and the Society for the Protection of Ancient Buildings. An enterprise of this nature which will mean at one and the same time the safeguarding of land for the development of scientific research and the preservation of a green belt in an area rapidly becoming industrialized, should have a double appeal : to those who think well of East Malling as a research centre, and to those also who approve of keeping part at least of the 'Garden of England' unspoilt. Such a project as the purchase and maintenance of Bradbourne must necessarily entail a heavy strain on the Station, and it may be several years before it is free from financial anxiety. Hence any contributions towards paying off the debt for the purchase and restoration will be welcomed by the Director, East Malling Research Station, Near Maidstone, Kent.

\section{B.M.A. Committee on Mental Health}

THE ever-recurring problems of sickness both in industry and in the general population which cannot be satisfactorily diagnosed or relieved by reference to the bodily symptoms alone, has led to a slowly developing interest into the mental aspect of disease. More than ten years ago, a report of the Industrial Health Research Board gave experimental evidence that led to the view that telegraphists' cramp was a psycho-neurotic manifestation. Studies of industrial sickness-absence show that much inefficiency, lost time and unhappiness are related to disorders of the type vaguely labelled nervous breakdown. Also investigations into industrial failures show that a large proportion are people whose disabilities are of a mental or emotional nature. It is therefore opportune that a special committee of the British Medical Association should be appointed to study the problem of mental health in general. The committee is to make a thorough study of all the available statistics and will seek to compare the importance of mental illness with other conditions already recognized by the State as requiring action. It will consider the part which the general practitioner, hospitals, clinics under the Mental Treatment Act, child guidance and other clinies, can play in the prevention of such iliness, and study the degree of success attainable by the present available methods of treatment. A very important part of the committee's work will be to consider the part allotted to psychological medicine in medical training. The members of the committee are as follows : Sir Robert Johnston (president), Sir Kaye le Fleming (chairman of council), Mr. H. Guy Dain (chairman of representative body), Mr. N. Bishop Harman (treasurer), Sir Henry Brackenbury. Dr. J. A. Brown, Dr. Millais Culpin, Dr. R. G. Gordon, Sir Walter Langdon-Brown, Dr. Mary C. Luff, Dr. E. Mapother, Dr. Doris M. Odlum, Dr. A. A. W. Petrie, Dr. J. R. Rees, Dr. Benjamin Reid, Dr. D. Stewart, and Dr. R. M. Stewart.

\section{Bureau of Human Heredity}

AN appeal for funds on behalf of the Bureau of Human Heredity, which appears in The Times of June 7, gives some slight indication of the value of the work which has been carried out by this organiza. tion with the limited resources at its disposal and in the brief period since its foundation. The function of the Bureau is to centralize in one organization as a world clearing-house the information already accurately ascertained on the inborn constitutional factors in man, and to distribute it freely wherever it is required. In less than eighteen months the Bureau has accumulated data on the inheritance of more than six hundred physical and mental differences. As a result of a financial appeal in May 1936 , the Bureau secured sufficient support to enable it to carry on from day to day, while a grant for one year was made by a scientific worker. The present appeal is headed by Lord Dawson of Penn, with the support of Sir F. Gowland Hopkins, Sir E. Farquhar Buzzard, Sir Richard Gregory and others. In their view, the facts warrant an appeal to the public for a sum of $£ 25,000$, an amount which is not considered excessive in view of the importance of the work to be carried on. It would enable the activities of the Bureau to be placed on a permanent basis. In justification, the signatories to the appeal point out that attempts to improve the lot of the individual must remain largely ineffective so long as the data which reveal his inborn nature remain obscure. When the Bureau has been placed in a position to carry out its functions normally in accordance with the intentions of its promoters, it will be possible for any medical man to obtain in English the latest information from any country relating to, for example, the resistance or non-resistance of certain types to common infections, or occupational disease. Research workers themselves are well aware that the organiza. tion of knowledge, such as that upon which the Bureau is engaged, is little less important for scientific progress than research itself. Without it there is risk that much valuable work may suffer oblivion. The appeal is issued from the Bureau of Human Heredity, 115 Gower Street, London, W.C.1.

\section{Haslemere Educational Museum}

ThE Haslemere Educational Museum will celebrate, on June 29, the fiftieth anniversary of its foundation. The speakers on the occasion will be Earl Winterton and Dr. John Ramsbottom. This museum was founded in $\mathbf{1 8 8 8}$ by Sir Jonathan Hutchinson, F.R.S., at a time when the majority of the smaller museums were stagnant and uninspiring because they lacked teachers. Hutchinson was a great teacher, and through. his teaching the museum at his country house at Inval, about a mile from Haslemere, quickly made its influence felt. There he arranged for the first time the space-for time schedules of geology and human history which are still a special feature of the museum, and these schedules were largely used in his lectures to friends and to members of the Haslemere Natural History Society. In less than ten years the Museum had completely outgrown itself, and Hutchinson then built a much more commodious one in Haslemere on the hillside to the south-east of the town, and there continued to lecture at weekends in the summer months. 